\title{
THE EFFECTIVENESS OF THERAPY BY CRYOPRESERVED HUMAN PLASMA IN PATIENTS WITH DEFICIENCY OF MANNOSE BINDING LECTIN SUFFERING FROM HERPES VIRUS INFECTION
}

DOI: 10.36740/WLek202108108

\author{
Larysa V. Natrus, Dmytro V. Maltsev, Yuliia G. Klys, Tetyana I. Panova \\ O.BOGOMOLETS NATIONAL MEDICAL UNIVERSITY, KYIV, UKRAINE
}

\begin{abstract}
The aim: To research the effectiveness of cryopreserved blood plasma replacement therapy in patients with primary mannose binding lectin (MBL) deficiency, suffering from chronic active herpes virus infections.

Materials and methods: Patients of the study group (SG) $n=36$ additionally received cryopreserved blood plasma therapy 0ctaplas (0ctapharma, Switzerland). Patients of the control group (CG) $n=36$ received only chemotherapy with Valganciclovir $450 \mathrm{mg} 2 /$ day per os for $1-3$ months. The diagnosis of active herpes virus infection was established by PCR of blood leukocytes. Statistical analysis of the obtained information was processed by the calculation of the chi-square (X2) Pearson criterion, the odds ratio and the associated $95 \%$ confidence interval $(95 \% \mathrm{Cl})$.

Results: The adding cryopreserved blood plasma substitute to standard therapy with valganciclovir for the treatment of chronic active herpes virus infection in patients with total serum MBL deficiency below $50 \mathrm{ng} / \mathrm{ml}$, allowed to get more negative $P C R$ results.

The effectiveness of combination therapy was 50\% higher in carrier of $H H V-6\left(X^{2}=8,533\right.$ and $p=0,004$; Yeats correction 6,533 and significance 0,$011 ; 0 R=11,667$ and $95 \%$ $\mathrm{Cl}=1,939-70,180)$ and $43 \%$ in carrier of $\mathrm{HHV}-7\left(\mathrm{X}^{2}=8,846\right.$ and $\mathrm{p}=0,003$; Yeats correction 7,165 and significance 0,$008 ; 0 \mathrm{R}=6,375$ and $\left.95 \% \mathrm{Cl}=1,711-23,758\right)$, compared with monotherapy. The close association between deficit MBL compensation and the results of antiviral treatment is also reported. The effect of such treatment in patients with chronic EBV infection was less (27\%).

Conclusions: We assumed, that virostatic effect of valganciclovir is increased by MBL-mediated clearance of blood serum from viral particles.
\end{abstract}

KEY WORDS: immunodeficiency, cryopreserved blood plasma substitute, valganciclovir

Wiad Lek. 2021;74(8):1824-1828

\section{INTRODUCTION}

Primary deficiency of mannose-binding lectin (MBL) occurs among $5-10 \%$ of Europeans [1,2] and belongs to the group of minor immunodeficiencies [3]. The disease is characterized by a genetically determined, associated with polymorphisms of the MBL2 gene (rs5030737), reduced production of a key component of lectin complement activation pathway, called mannose-binding protein [1-6].

MBL is important for anti-infectious $[7,8]$ and antitumor [9] protection of the human body, carried out through the recognition of mannose residuals on the surface of foreign and infected cells, with the subsequent formation of membrane-attacking complexes. Furthermore, MBL participates in the regulation of inflammation and in the prevention of autoimmune complications, potentiating the removal of apoptotic bodies and elements of tissue detritus [1,3].

The results of the meta-analysis of randomized controlled clinical trials showed the association of primary MBL deficiency with the bacterial sepsis development in children [6]. In a retrospective study of Justice J.M. et al. MBL deficiency was identified in 33\% of adults with constantly recurrent rhinosinusitis caused by Staphylococcus aureus, coagulase-negative Staphylococcus species and Pseudomonas aeruginosa. The prevalence rate of this immunodeficiency in this cohort was 4 times higher than in general population [8]. Primary MBL deficiency is an important reason for performing adenoid- and tonsillectomy, as it mediates the formation of persistently recurring bacterial infections of the tonsils within the lymphopharyngeal ring [10].

There are evidences of association of MBL deficiency with severe infections induced by herpes simplex viruses type 1 [7] and 2 [11], Epstein-Barr virus [12], cytomegalovirus [13], herpes simplex viruses 6 and 7 types [2], papillomaviruses [14] and TT virus [15].

Effective methods of substitution therapy for this immunodeficiency have not been developed yet. It is known, that in case of deficiency of proteins in the complement system, plasma substitutes, that contain the necessary proteins from the blood of healthy donors, are used. In accordance with that, Valdimarsson H. reported a number of clinical cases, where the freshly frozen blood plasma was successfully used for the treatment of persistently recurring herpes virus infection in patients with primary MBL deficiency 
[16]. It seems appropriate to initiate a special clinical study to investigate the effectiveness of plasma substitutes, which contain donor MBL molecules, in clinically manifest forms of primary MBL deficiency in humans.

\section{THE AIM}

To research the effectiveness of cryopreserved blood plasma replacement therapy in patients with primary MBL deficiency, suffering from chronic active herpes virus infections.

\section{MATERIALS AND METHODS}

In total in the period from 2018 till 201972 adult patients aged from 19 to 54 years old with verified primary MBL deficiency and the clinical picture of chronic active herpes virus infection received therapy. Examination and treatment were conducted in a specialized clinic with the written consent of the patient to participate in the study (Protocol No. 128 of 12/23/2019, Bioethics Commission of the NMU named after A.A. Bogomolets).

The concentration of MBL in the serum below $50 \mathrm{ng} / \mathrm{ml}$ was considered the total MBL deficit, while its level between 450 and $50 \mathrm{ng} / \mathrm{ml}$ was referred to partial deficit.

The diagnosis of primary MBL deficiency was established based on the detection by PCR with restriction of one pathogenic polymorphism in the promoter simultaneously with one or more pathogenic polymorphisms in the structural genes MBL2 (rs5030737) - 221CG, 239GC, 550GC, 223CT, 230GC.

Herpes virus infection in patients participating in the study manifested through persistent subfebrile hyperthermia, pharyngitis, feeling weak, fatigue, patient's distress, lymphadenopathy, hepatosplenomegaly, arthralgia and myalgia, persistent lymphomonocytosis in the blood formula, sometimes with a slight increase in atypical mononuclear cell and blood sedimentation rate.

The patients from the study group (SG) $(n=36)$ received replacement therapy with cryopreserved blood plasma Octaplas (Octapharma, Switzerland). According to the data provided by the manufacturer, the average content of MBL in the plasma substitute was $763 \mathrm{ng} / \mathrm{ml}$ (range 567-931 ng / ml). Octaplas was administered as an intravenous drip infusion at a dose of $10 \mathrm{ml} / \mathrm{kg}$ in accordance with patient's blood type once in 2 weeks during 3 months (6 infusions). Additionally all patients received valine ester of ganciclovir (Valganciclovir) $450 \mathrm{mg}, 2 /$ day per os for the period of 1-3 months

The patients from control group $(\mathrm{CG})(\mathrm{n}=36)$ received only chemotherapy with Valganciclovir $450 \mathrm{mg}$ 2/day per os for 1-3 months.

The diagnosis of active herpes virus infection was established by PCR of blood leukocytes.

CG matched the SG by age, gender and virus types distribution.

In patients from SG EBV infection was diagnosed in $11 / 36$ patients (31\%), HHV-6 - in 16/36 (44\%) and HHV7 in $23 / 36$ (64\%). In $14 / 36$ cases (39\%), there was mixed infection, in which DNA of herpes viruses of two different species was detected. In CG mixed infection was detected in $13 / 36(36 \%)$ cases.
The serum MBL concentration was measured with ELISA (manufacturer of panel) before starting therapy and the day after each administration of plasma substitute. Treatment success was assessed by the results of PCR of blood leukocytes.

Statistical analysis of the obtained information was processed by the methods of structural and comparative analysis. The average values and the average error were calculated. To study the significance of the differences between the groups Student $\mathrm{t}$-test with confidence figure indicator $\mathrm{p}$ and the nonparametric criterion for the sign numbers $\mathrm{Z}$ according to Y.V. Urbakh were applied. To study the relation between immunotherapeutic treatment and the PCR results, the chi-square $\left(\chi_{2}\right)$ Pearson criterion was used, comparing the obtained value with the tabulated one at a given number of freedom degrees and confidence levels $p=0.05$ and $p=0.01$. For actual values from 5 to 9 , the Yeats correction was additionally applied, and for the values less than 5 the exact Fisher test was used. The odds ratio and the associated $95 \%$ confidence interval were also calculated. To assess the strength of the connection between the indicated factor and the outcome, additionally the $\varphi$ criterion (criterion V Cramer, criterion K Chuprova), the Pearson contingency coefficient $(\mathrm{C})$ and the standardized value of the Pearson coefficient $\left(C^{\prime}\right)$ were also used.

\section{RESULTS}

We suggested, that immunotherapy will accelerate the removal of viral DNA from blood cells and increase the number of responders to treatment. We assumed, that this effect will be caused by the combination of virostatic effects of valganciclovir and the virucide effects of a blood plasma substitute. We investigated whether the increase in MBL-mediated clearance of blood serum from viral particles, caused by the administration of blood plasma substitute, will improve the therapy outcome of chronic active herpes virus infection.

Therapy was considered successful if, after a course of treatment, patients received a negative result of PCR of blood leukocytes with specific primers of herpes viruses.

More successful therapy in SG compared with CG was established (table I). Differences in treatment effects were significant in $H H V-6$ and $H H V-7$ infections. Such patients had a low sensitivity to 3-month therapy with valganciclo$\operatorname{vir}(35 \%$ and $38 \%$ cases). The significance of differences in treatment effects as a result of the blood plasma substitute was statistically reliable $\left(\mathrm{p}<0,05 ; \mathrm{Z}<\mathrm{Z}_{0,05}\right)$. EBV infection in $55 \%$ of cases responded to valganciclovir treatment without significant differences with CG $(p>0,05)$. These obtained results can be controversial due to a smaller number of patients with chronic active $E B V$ infection

The results of $\chi^{2}$, Yates correction, the exact Fisher test calculation highlights the obvious benefit of adding immunotherapy with a blood plasma substitute to a standard chemotherapy with valganciclovir for $\mathrm{HHV}-6$ and $\mathrm{HHV}-7$ infections, but not for reactivated $E B V$ infection (table II).

There is a relatively strong association by $\varphi$ criterion, coefficient $C$ and C' between the introduction of blood plasma substitute to the patient's treatment scheme and 
Table I. Absolute and relative ratio of negative PCR results of each type of virus in patients after treatment.

\begin{tabular}{ccccc}
\hline Virus & SG & N negative/ N carrier & CG & N negative/ N carrier \\
\hline EBV & $9 / 11$ & $82 \%$ & $6 / 11$ & $55 \%$ \\
\hline$H H V-6$ & $14 / 16$ & $88 \%$ & $6 / 16$ & $38 \%$ \\
\hline$H H V-7$ & $18 / 23$ & $78 \%$ & $8 / 23$ & $35 \%$ \\
\hline
\end{tabular}

Table II. The results of comparing the differences in treatment success in groups of patients by the number of negative PCR tests after treatment.

\begin{tabular}{|c|c|c|c|c|c|c|c|c|c|c|}
\hline Virus & N SG & N CG & $x^{2}$ & $\begin{array}{c}X^{2} \text { at } \\
p=0,05\end{array}$ & $\begin{array}{c}X^{2} \text { at } \\
p=0,01\end{array}$ & Significance & $\begin{array}{c}\text { Yates's } \\
\text { Correction }\end{array}$ & Significance & $\begin{array}{l}\text { Fisher's } \\
\text { exact test }\end{array}$ & Significance \\
\hline$E B V$ & 9 & 6 & 1,886 & 3,841 & 6,635 & $p=0.170$ & 0,838 & 0.360 & 0,21246 & $p>0,05$ \\
\hline$H H V-6$ & 14 & 6 & 8,533 & 3,841 & 6,635 & $p=0,004$ & 6,533 & 0,011 & 0,00489 & $p<0,05$ \\
\hline$H H V-7$ & 18 & 8 & 8,846 & 3,841 & 6,635 & $p=0,003$ & 7.165 & 0,008 & 0,00672 & $p<0,05$ \\
\hline
\end{tabular}

Table III. Indexes, demonstrating the strength of the association between immunotherapy and PCR in the SG $(n=36)$

\begin{tabular}{|c|c|c|c|c|c|c|}
\hline \multirow[b]{2}{*}{ Index } & \multicolumn{2}{|c|}{ EBV } & \multicolumn{2}{|c|}{ HHV-6 } & \multicolumn{2}{|c|}{ HHV-7 } \\
\hline & Index value & $\begin{array}{l}\text { Strength } \\
\text { of the } \\
\text { association }\end{array}$ & $\begin{array}{l}\text { Index } \\
\text { value }\end{array}$ & $\begin{array}{c}\text { Strength } \\
\text { of the } \\
\text { association }\end{array}$ & Index value & $\begin{array}{c}\text { Strength } \\
\text { of the } \\
\text { association }\end{array}$ \\
\hline $\begin{array}{c}\varphi \text { coefficient } \\
\text { Cramér's V index } \\
\text { Criterion K Chuprova }\end{array}$ & 0.293 & moderate & 0.516 & Relatively strong & 0,439 & Relatively strong \\
\hline Pearson Conjugation Ratio (C) & 0.281 & moderate & 0.459 & Relatively strong & 0,402 & Relatively strong \\
\hline $\begin{array}{l}\text { Normalized Pearson coefficient } \\
\qquad\left(C^{\prime}\right)\end{array}$ & 0.397 & moderate & 0.649 & strong & 0,568 & Relatively strong \\
\hline
\end{tabular}

Table IV. Odds ratio (OR) and the $95 \%$ confidence interval calculation of PCR results in SG $(n=36)$ and CG $(n=36)$

\begin{tabular}{cccccc}
\hline Virus & SG & CG & OR & S & 95\% CI \\
\hline$E B V$ & 9 & 6 & 3,750 & 0,989 & $0,540-26.046$ \\
\hline$H H V-6$ & 14 & 6 & 11,667 & 0,915 & $1,939-70,180^{*}$ \\
\hline$H H V-7$ & 17 & 8 & 6,375 & 0,671 & $1,711-23,758^{*}$ \\
\hline
\end{tabular}

Table V. Results of chi-square analysis of negative PCR in SG1 and SG2 patients

\begin{tabular}{ccccccccccc}
\hline Virus & N SG1 & N SG2 & $\mathbf{X}^{\mathbf{2}}$ & $\begin{array}{c}\mathbf{X} \text { at } \\
\mathbf{p}=\mathbf{0 , 0 5}\end{array}$ & $\begin{array}{c}\mathbf{X} \text { at } \\
\mathbf{p}=\mathbf{0 , 0 1}\end{array}$ & Significance & $\begin{array}{c}\text { Yates's } \\
\text { Correction }\end{array}$ & Significance & $\begin{array}{c}\text { Fisher's } \\
\text { exact test }\end{array}$ & Significance \\
\hline$E B V$ & $6 / 5$ & $5 / 4$ & 0,020 & 3,841 & 6,635 & $\mathrm{p}=0,887$ & 0,413 & 0.521 & 0,020 & $\mathrm{p}>0,05$ \\
\hline$H H V-6$ & $15 / 15$ & $3 / 1$ & 11,250 & 3,841 & 6,635 & $\mathrm{p}<0,001$ & 5,513 & 0,019 & 0,01961 & $\mathrm{p}<0,05$ \\
\hline$H H V-7$ & $14 / 14$ & $9 / 5$ & 9.938 & 3,841 & 6,635 & $\mathrm{p}=0,002$ & 6,941 & 0,009 & 0,00374 & $\mathrm{p}<0,05$ \\
\hline
\end{tabular}

Table VI. The results of the odds ratio (OR) and the 95\% confidence interval of PCR blood analysis in SG1 and SG2

\begin{tabular}{cccccc}
\hline Virus & SG1 $\mathbf{n = 2 3}$ & SG2 $\mathbf{n = 1 3}$ & OR & S & 95\% CI \\
\hline$E B V$ & $6 / 5$ & $5 / 4$ & 1,250 & 1,565 & $0,058-26,870$ \\
\hline$H H V-6$ & $15 / 15$ & $3 / 1$ & - & - & - \\
\hline$H H V-7$ & $14 / 14$ & $4 / 5$ & - & - & - \\
\hline
\end{tabular}

the negative PCR results in patients with chronic active $H H V-6$ and $H H V-7$. In patients with EBV this association is average (table III). These data are confirmed by the results of OR and 95\% CI calculation (table IV).

The obtained results demonstrate, that the adding cryopreserved blood plasma substitute to standard therapy with valganciclovir is a therapeutic tactic, represented by the significant increase in number of therapy responders.

An important question is what the mechanism of this positive influence may be. We checked whether the achieved effect is related to the restoration of the serum MBL pool. 
The changes of the MBL serum concentration over the treatment period in patients with SG and CG were investigated (fig. 1).

Diagram demonstrates a significant increase in the MBL serum concentration at each observation point throughout the entire therapy course with a full recovery in $65 \%$ of cases, mainly in individuals with partial lectin deficiency $(\mathrm{p}<0,05$; $\mathrm{Z}<\mathrm{Z}_{0,05}$ ). In the CG, there were no significant changes in the MBL serum concentration over the treatment period in comparison with initial level.

There were 2 subgroups in the SG, which differed in the concentration of MSL after a course of combination therapy. SG1 included 23 SG patients with normalization of the MBL concentration in blood serum. SG2 encompassed the remaining 13 SG patients, who had partial immunodeficiency substitution. In order to establish whether there is a connection between the restoration of the MBL serum concentration and the results of antiviral treatment, we conducted the calculation of $\chi^{2}$, OR. 95\% CI in SG1 and SG2 (table V,VI)

It is demonstrated, that the normalization of MBL serum concentration, achieved by the blood plasma replacement therapy, is closely associated with the positive outcome of patient's treatment with active $H H V-6$ - and $H H V-7-$ infection, but not EBV-infection.

These data suggest that the restoration of the MBL serum concentration after the substitution immunotherapy in patients with primary MBL deficiency positively affected the results of antiviral treatment with valganciclovir, and the achieved antiviral effect was associated with the blood plasma infusion and restoration of the serum MBL pool.

\section{DISCUSSION}

Primary MBL deficiency is a common immunodeficiency in the population, which can lead to infectious, autoimmune, immunoinflammatory, allergic and oncological lesions $[7,9,11,17]$. It seems obvious the relevance for development of replacement immunotherapy for this immunodeficiency, which can help in the treatment and prevention of severe immune-dependent manifestations of this disease. The success of immunoglobulin replacement therapy in primary humoral immunodeficiencies should contribute to the intensification of attempts to develop and test replacement immunotherapy in primary MBL deficiency [18]. In the case of genetic deficiencies of some other proteins of the human complement system, blood plasma preparations containing these proteins from the body of healthy donors have been already successfully tested in the 70 s of the last century [19]. Therefore, the use of human plasma preparations in primary MBL deficiency appears to be a potentially appropriate therapeutic strategy, given the lack of alternative approaches to immunosupportive treatment in clinically manifest cases.

Until now, attempts to test replacement immunotherapy in primary MBL deficiency in humans have been already conducted. The first experiment was the use of a fresh frozen human blood plasma for the relief of recurrent erythema multiforme associated with herpes simplex virus type 1 in a child with primary MBL deficiency. In this case, blood plasma with MBL deficiency didn't give a clinical result [16]. Then there were reports of successful cases of replacement immunotherapy with purified natural MBL, obtained from the blood plasma of healthy donors $[16,20]$.

The results of several clinical studies have confirmed the benefits of using natural MBL in clinically manifest forms of primary MBL deficiency in humans, but such medications have not been introduced to the pharmaceutical market [21,22]. Subsequently, studies of the recombinant $\mathrm{MBL}$, obtained by genetic engineering, were conducted for the purpose of immune replacement therapy in primary MBL deficiency in humans. Preliminary results of such testing have shown the safety and high tolerability of the recombinant MBL molecule and the ability of the medication to restore the serum lectin pool in immunocompromised individuals, but phase II and III of clinical trials have not been conducted [23]. Therefore, the replacement of immunodeficiency with fresh frozen or cryopreserved human blood plasma seems to be the only available strategy of basic therapy for patients with primary MBL deficiency who develop intractable immune-dependent manifestations.

Results of this study shed light on the ways of improving the effectiveness of chronic active herpes virus infections treatment in patients with primary MBL deficiency. It has been demonstrated that adding blood plasma substitute to the standard valganciclovir therapy can significantly increase the number of positive results in the treatment of $H H V-6$ and $H H V-7$. These effects are achieved through the significant increase of the serum MBL concentration under the influence of immunotherapy. Normalization of the serum MBL concentration in patients with primary MBL deficiency is associated with an increase in the number of responders to antiviral therapy with valganciclovir in chronic active $H H V-6$ and $H H V-7$ infections.

Nevertheless, thelack of benefit from the plasma substitute for $E B V$ treatment is observed. These results can be associated with both a small number of participants and the higher sensitivity of this virus to valganciclovir.

Not excluding the possibility of a complex positive effect of blood plasma as a multicomponent drug on the reproductive herpes virus's activity, it should be concluded, that exactly the replacement of MBL deficiency with donor molecules is an important component of therapeutic success in patients with primary deficiency of this lectin.

\section{CONCLUSIONS}

The adding blood plasma substitute to the standard valganciclovir therapy of chronic active herpes virus infections in patients with MBL deficiency allows to get more negative PCR results of blood leukocytes. The effectiveness of combination therapy is 50\% higher for HHV-6- and $43 \%$ - for HHV-7-infections compared with monotherapy. The patients, who received combination therapy, represented a normalization of serum 
MBL concentration in $65 \%$ of cases. The close association between deficit MBL compensation and the results of antiviral treatment is also reported. We assumed, that virostatic effect of valganciclovir during combination therapy is increased by MBL-mediated clearance of blood serum from viral particles.

Further randomized controlled clinical trials are requires in order to study the effectiveness of substitution therapy with cryopreserved blood plasma in patients with primary MBL deficiency, manifested both in the form of chronic active herpesvirus infections and other infectious diseases.

\section{REFERENCES}

1. Maltsev D.V. Defitsyt mannozozv"yazuval'noho bilka [Mannose binding protein deficiency].Ukrayins'kyy terapevtychnyy zhurnal. 2015;1:8089. (In Ukrainian)

2. Maltsev D.V. Klinichni vypadky defitsytu mannozozv"yazuval'noho bilka [Clinical cases of mannose binding protein deficiency]. Ukrayins'kyy medychnyy chasopys. 2015;2(106):122-127. (In Ukrainian)

3. Maltsev D.V. Mali imunodefitsytni khvoroby [Mild immunodeficiency diseases]. Tsentr uchbovoyi literatury. 2015, 460 p. (In Ukrainian)

4. Christiansen 0.B., Nielsen H.S., Lund M. et al. Mannose-binding lectin-2 genotypes and recurrent late pregnancy losses. Hum. Reprod.2009; 24(2): 291-299.

5. Eurich D., Boas-Knoop S., Morawietz L. et al. Association of mannosebinding lectin-2 gene polymorphism with the development of hepatitis C-induced hepatocellular carcinoma. Liver. Int. 2011;31(7):1006-1012.

6. Gao D.N., Zhang Y., Ren Y.B. et al. Relationship of Serum MannoseBinding Lectin Levels with the Development of Sepsis: a Meta-analysis. Inflammation. 2014; 38(1);338-347.

7. Alstadhaug K.B., Kvarenes H.W., Prytz J. et al. A case of relapsingremitting facial palsy and ipsilateral brachial plexopathy caused by HSV-1. J.Clin. Virol. 2016;78: 62-65.

8. Justice J.M., Sleasman J.W., Lanza D.C. Recalcitrant Rhinosinusitis, Innate Immunity, and Mannose-Binding Lectin.Ann. Otol. Rhinol. Laryngol. 2014; 124(2):102-106.

9. Schuffenecker I., Narod S.A., Ezekowit R.A.B. et al. The gene for mannosebinding protein maps to chromosome 10 and is a marker for multiple endocrine neoplasia type 2. Cytogenet. Cell Genet.1991; 56: 99-102.

10. Koturoglu G., Onay H., Midilli R. et al. Evidence of an association between mannose binding lectin codon 54 polymorphism and adenoidectomy and/or tonsillectomy in children. Int. J. Pediatr. Otorhinolaryngol. 2007; 71(8):1157-1161.

11. Tang Y.W., Cleavinger P.J., Li H. et al. Analysis of candidate-host immunogenetic determinants in herpes simplex virus-associated Mollaret's meningitis. Clin. Infect. Dis. 2000; 30(1):176-178.

12. Friborg J.T., Jarrett R.F., Koch A. et al. Mannose-binding lectin genotypes and susceptibility to epstein-barr virus infection in infancy. Clin.Vaccine Immunol. 2010; 17(9): 1484-1487.

13. Manuel 0., Pascual M., Trendelenburg M., Meylan P.R. Association between mannose-binding lectin deficiency and cytomegalovirus infection after kidney transplantation. Transplantation. 2007;83(3):359-362.

14. Segat L., Crovella S., Comar M. et al. MBL2 gene polymorphisms are correlated with high-risk human papillomavirus infection but not with human papillomavirus-related cervical cancer. Hum. Immunol. 2009; 70(6):436.

15. Maggi F., Pifferi M., Michelucci A. et al. Torque teno virus viremia load size in patients with selected congenital defects of innate immunity. Clin. Vaccine Immunol. 2011; 18(4):692-694.
16. Valdimarsson H. Infusion of plasma-derived mannan-binding lectin (MBL) into MBL-deficient humans. Biochem. Soc. Trans. 2003; 31(4):768-769.

17. Birbian N., Singh J., Jindal S.K. et al. Association of the wild-type A/A genotype of MBL2 codon 54 with asthma in a North Indian population. Dis. Markers. 2012; 32(5): 301-308.

18. van Kessel D.A., Hoffman T.W., van Velzen-Blad H. et al. Long-term Clinical Outcome of Antibody Replacement Therapy in Humoral Immunodeficient Adults With Respiratory Tract Infections. EBioMedicine. 2017; 18: 254-260.

19. Cohen G., Peterson A. Treatment of hereditary angioedema with frozen plasma. J Allergy Clin Immunol. 1973; 51(7): 45-56.

20. Garred P., Pressler T., Lanng S. et al. Mannose-binding lectin (MBL) therapy in an MBL-deficient patient with severe cystic fibrosis lung disease. Pediatr. Pulmonol. 2002; 33: 201-207.

21. Frakking F.N., Brouwer N.M., van de Wetering D. et al.. Safety and pharmacokinetics of plasma-derived mannose-binding lectin (MBL) substitution in children with chemotherapy-induced neutropaenia. Eur. J. Cancer. 2009; 45: 505-512.

22. Bang P., Laursen I., Thornberg K. et al. The pharmacokinetic profile of plasma-derived mannan-binding lectin in healthy adult volunteers and patients with Staphylococcus aureus septicaemia. Scand J Infect Dis. 2008;40(1):44-48.

23. Petersen K.A., Matthiesen F., Agger T. Phase I safety, tolerability, and pharmacokinetic study of recombinant human mannan-binding lectin J Clin Immunol. 2006; 26(5): 465-475.

To conduct this study, a grant from Octapharma was received. The study was carried out as a fragment of scientific work commissioned by the Ministry of Health of Ukraine, grant No. 0121 U107940.

\section{ORCID and contributionship:}

Larysa V. Natrus: 0000-0003-1763-0618 ${ }^{A, D}$

Dmytro V. Maltsev: 0000-0002-6615-3072 ${ }^{B, C}$

Yuliia G. Klys: 0000-0002-4401-803X ${ }^{D, F}$

Tetyana I. Panova: 0000-0002-0298-802X ${ }^{E, F}$

\section{Conflict of interest:}

The Authors declare no conflict of interest.

\section{CORRESPONDING AUTHOR}

\section{Larysa V. Natrus}

0.Bogomolets National Medical University

34 Peremogu Ave., 03115, Kyiv, Ukraine

tel: +380501780777

e-mail:Lnatrus777@gmail.com

Received: 15.07 .2020

Accepted: 02.06 .2021

A - Work concept and design, B - Data collection and analysis, C - Responsibility for statistical analysis,

D-Writing the article, $\mathbf{E}$-Critical review, $\mathbf{F}$ - Final approval of the article 